ERRATUM

\title{
Influence of Catchment-Scale Military Land Use on Stream Physical and Organic Matter Variables in Small Southeastern Plains Catchments (USA)
}

\section{KELLY O. MALONEY*}

Department of Biological Sciences

Auburn University

331 Funchess Hall

Auburn, Alabama 36849-5407, USA

\section{PATRICK J. MULHOLLAND}

Environmental Sciences Division

Oak Ridge National Laboratory

Oak Ridge, Tennessee 37831, USA

\section{JACK W. FEMINELLA}

Department of Biological Sciences

Auburn University

331 Funchess Hall

Auburn, Alabama 36849-5407, USA
RE: Environmental Management Vol. 35, No. 5. pp. 677-691: The slope units used for the land-use classification were incorrect. Text on page 681, column 1 , line 16 , should have read "...occurring in a par- ticular land-use class on slopes " $<3^{\circ}(\sim 5 \%)$ ". Text on page 681 , column 1 , lines 19,32 , and 40 , and column 2 heading of Table 2 should have read " $>3^{\circ}$ ", instead of " $>3 \%$ ".

Published online: October 28, 2005.

*Author to whom correspondence should be addressed; email: malonko@auburn.edu 